Vol 3 No 3 September 2020

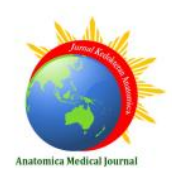

E-ISSN: 2614-5219

ARTIKEL PENELITIAN

\title{
Uji Resistensi Insektisida Golongan Karbamat Terhadap Larva Nyamuk Aedes Aegypti Di Kecamatan Medan Denai
}

\author{
Muhammad Teguh Syahputra ${ }^{1}$, Nurfadly ${ }^{2}$ \\ ${ }^{1}$ Fakultas Kedokteran Universitas Muhammadiyah Sumatera Utara \\ ${ }^{2}$ Departemen Parasitologi Universitas Muhammadiyah Sumatera Utara \\ Email : drnurfadly@gmail.com
}

\begin{abstract}
Abstrak: Nyamuk Aedes aegypti adalah nyamuk yang paling sering menyebabkan penyakit Demam Berdarah Dengue (DBD). Berbagai macam upaya telah dilakukan untuk pengendalian nyamuk Aedes aegypti salah satunya dengan cara penyemprotan (fogging) insektisida golongan karbamat. Penggunaan dari insektisida golongan karbamat yang tidak rasional dapat menyebabkan peningkatan enzim asetilkolinesterase sehingga dapat menimbulkan resistensi terhadap nyamuk Aedes aegypti. Tujuan: Mengetahui status resistensi larva nyamuk Aedes aegypti terhadap insektisida golongan karbamat di Kecamatan Denai kota Medan. Metode: Penelitian ini merupakan penelitian deskriptif dengan menggunakan metode potong lintang dimana menggunakan 276 larva nyamuk Aedes aegypti. Hasil Penelitian: Hasil penelitian diperoleh larva nyamuk Aedes aegypti yang rentan terhadap insektisida golongan karbamat sebesar $66.3 \%$ dan sebesar $33.7 \%$ larva nyamuk Aedes aegypti toleran terhadap insektisida golongan karbamat dan larva nyamuk Aedes aegypti yang bersifat resisten tidak dijumpai. Kesimpulan: Sebanyak 33.7\% larva nyamuk Aedes aegypti toleran terhadap insektisida golongan karbamat.
\end{abstract}

Kata Kunci: larva Aedes aegypti, insektisida, karbamat

\section{Resistance Test of Aedes aegypti Larvae to Carbamate Insecticide In Kecamatan Medan Denai}

Abstract: Aedes aegypti is the main vector mosquito that causes Dengue Hemorrhagic Fever $(D H F)$. Various efforts have been made to control the Aedes aegypti mosquito by fogging carbamate insecticides. The use of an irrational carbamate insecticide causes an increase in the acetylcholinesterase enzyme so that caused resistance to the Aedes aegypti larvae. Objective: To determine the resistance status of Aedes aegypti larvae to insecticides of the karbamat group in Kecamatan Medan Denai. Method: This study was a descriptive research design with cross sectional design, which used 276 Aedes aegypti larvae. Results: The results of this study found $66.3 \%$ of larvae that were susceptible to carbamate insecticide, $33.7 \%$ of larvae were tolerant to carbamate insecticides and resistant larvae were not found. Conclusion: 33.7\% of Aedes aegypti larvae are tolerant to carbamate insecticides.

Keywords: larvae of Aedes aegypti, insecticides, carbamate 


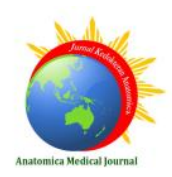

E-ISSN: 2614-5219

\section{PENDAHULUAN}

Penyakit Demam Berdarah Dengue (DBD) disebabkan nyamuk jenis Aedes aegypti. Nyamuk ini aktif di pagi hari sampai siang hari. Nyamuk betina yang melakukan pengisapan darah dalam penyakit DBD. Dikarenakan nyamuk betina memerlukan protein untuk menghasilkan telurnya. ${ }^{1,2,3}$

Pada 100 kasus penyakit DBD dihasilkan 1 hingga 3 manusia meninggal dunia dikarenakan penyakit DBD ini. 50 sampai 100 juta manusia sudah terinfeksi setiap tahun di beberapa negara berkembang dengan pravelensi antara $1 \%$ hingga $2,5 \% .^{2,4}$

Data rerata nasional di Indonesia menunjukkan bahwa DBD merupakan penyakit endemis yang meningkat jumlah insidennya setiap tahun. Pada 100.000 penduduk didapatkan 27,67 penduduk di tahun 2011. Pada tahun 2012 sebanyak 37,27, di tahun 2014 sebesar 45,85 dan tahun 2015 sebesar 50,75 untuk per 100.000 masyarakat. Tahun 2012, jumlah kasus DBD ditemukan 4.367 kasus pada 33 per 100.000 warga. Penduduk Medan relatif tinggi terinfeksi DBD per 100.000 penduduk mulai tahun $2005 .^{4,5}$

Berbagai macam upaya telah dilakukan untuk pengendalian nyamuk Aedes aegypti, akan tetapi belum mencapai hasil yang begitu maksimal. Upaya pengendaliannya terutama akan ditujukan untuk pemutusan rantai penularan yaitu dengan cara memberantas nyamuk dewasanya dengan penyemprotan insektisida. Sampai sekarang masih sering dijumpai penyemprotan yang tidak tepat dosis, tidak tepat sasaran, tidak mengacu pada informasi tentang vektor. Sehingga hal yang seperti inilah yang dapat memicu terjadinya resistensi insektisida pada nyamuk Aedes aegypti di beberapa daerah. Insektisida dibagi dalam: insektisida organik, yang berasal dari alam dan insektisida organik sintetik. Insektisida organik sintetik terdiri atas golongan organik klorin (DDT, klorden, dieldrin, linden), golongan organik fosfor (malathion, temefos, parathion, diazinon, fenitrotion, diptereks), golongan organik nitrogen (dinitrofenol), golongan sulfur (karbamat) dan golongan tiosianat. Jenis insektisida yang biasa digunakan masyarakat dalam pengendalian vektor diantaranya ialah organofosfat, karbamat dan piretroid. ${ }^{6,7}$

Organokarbamat atau karbamat merupakan turunan dari asam karbamik yang kerjanya mirip dengan organofosfat yaitu menghambat enzim asetilkolinestrase pada sistem saraf . Ada dua bahan aktif karbamat 


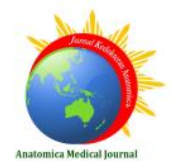

E-ISSN: 2614-5219

yang sering digunakan di Indonesia yaitu propoxur dan bendiokarb. Insektisida karbamat bekerja terhadap enzim asetilkolinesterase yang berfungsi mengendalikan hidrolisis dari asetilkolin, yaitu neurotransmitter yang dihasilkan di vesikel akson. Asetilkolin dan asetilkolinesterase akan dihidrolisis menjadi kolin dan asam asetat setelah impuls diteruskan. Ketika asetilkolinesterase tidak terdapat, asetilkolin yang dihasilkan akan berakumulasi sehingga terjadi gangguan transmisi impuls. ${ }^{7,8}$

Salah satu mekanisme resistensi terjadi apabila adanya peningkatan dari jumlah enzim esterase. Insektisida yang memiliki ikatan ester yang dapat dihidrolisis oleh enzim esterase. Insektisida golongan karbamat menyebabkan penghambatan pada asetilkolinesterase dengan cara karbamilasi dari residu serin pada asetilkolinesterase. ${ }^{79} 10$

\section{METODE PENELITIAN}

\section{Jenis Penelitian}

Penelitian ini merupakan penelitian jenis deskriptif dengan menggunakan metode potong lintang. Dimana penelitian ini menentukan status resistensi larva nyamuk Aedes aegypti yang berasal dari suatu daerah yaitu Kecamatan Medan Denai di Kota Medan terhadap insektisida golongan karbamat.

Sampel larva nyamuk Aedes aegypti sebagai bahan uji dikumpulkan sebanyak 100 ekor larva nyamuk dari rumah-rumah yang ada di Kecamatan Medan Denai. Teknik pengumpulan data yaitu berdasarkan hasil pengujian larva nyamuk Aedes aegypti terhadap insektisida golongan karbamat dengan uji biokimia.

\section{Cara Kerja}

Larva yang sudah dikumpulkan adalah larva stadium instar 3-4. Pengambilan larva dilakukan dengan menggunakan wadah penampungan yang berisi air yang bersih sebagai tempat indukan dari larva nyamuk. Pengambilan larva nyamuk Aedes aegypti langsung dari tempat indukannya bertujuan untuk menghindari larva yang berasal dari satu perindukan yang sama, sehingga mempunyai sifat resistensi yang sama terhadap insektisida karbamat. Identifikasi dari larva Aedes aegypti dilakukan di Laboratorium Parasitologi Fakultas Kedokteran Universitas Muhammadiyah Sumatera Utara. Resistensi larva nyamuk terhadap insektisida golongan karbamat adalah ketahanan yang dimiliki oleh suatu populasi nyamuk untuk mentolerir dosis 


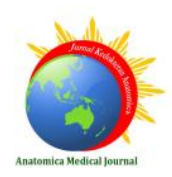

E-ISSN: 2614-5219

toksik insektisida golongan karbamat yang bisa menyebabkan kematian pada mayoritas populasi nyamuk normal pada spesies yang sama.

Uji aktivitas enzim asetilkolin esterase dilakukan dengan menggunakan QuantiChrom $^{T M}$ Acetilcholinesterase Assay Kit. Di dalam bioassay kit tersebut berisi assay buffer, reagen dan kalibrator. Larva nyamuk instar III-IV digerus secara individual untuk dibuat homogenat dan dilarutkan dengan $0,5 \mathrm{ml}$ larutan phosphat buffer saline (PBS) 0,1 M, pH = 7,5. Kemudian disentrifuge pada $14.000 \mathrm{rpm}$ selama 5 menit. Supernatan kemudian dipindahkan ke dalam microplate menggunakan micro-pipette untuk pemeriksaan. Reagen yang telah disiapkan dengan menambahkan 200 ul assay buffer ke dalam $2 \mathrm{mg}$ reagen, kemudian divorteks agar larut. Masukkan 190 ul campuran reagen ke dalam masing-masing sumuran yang berisi supernatan pada microplate, ketuk-ketuk sebentar agar bercampur. Masukkan microplate ke dalam Elisa reader, dibaca dengan Optical Density (OD) atau disebut juga absorbance value (AV) pada panjang gelombang $412 \mathrm{~nm}$ pada menit ke 2 dan menit 10. Nilai AV dibaca dari OD menit ke 10. Kadar enzim asetilkolinesterase dihitung dengan rumus sebagai berikut:

AchE Activity

$$
\begin{aligned}
& =\frac{O D_{10}-O D_{2}}{O D_{k a l}-O D_{H_{2} O}} \times n \\
& \times 200(U / L)
\end{aligned}
$$

Dimana :

- $\mathrm{OD}_{2}$ dan $\mathrm{OD}_{10}$ adalah nilai absorbansi yang terbaca pada menit ke 2 dan menit ke 10

- $\mathrm{OD}_{\mathrm{kal}}$ dan $\mathrm{OD}_{\mathrm{H} 2 \mathrm{O}}$ adalah OD pada kalibrasi dan $\mathrm{H}_{2} \mathrm{O}$ yang dibaca pada menit ke 10

- $\mathrm{n}$ adalah faktor pengenceran, karena tidak diencerkan maka $\mathrm{n}=1$

- Angka 200 adalah equivalen activity pada kalibrator pada kondisi pengujian

\section{Analisa Data}

Analisis data dilakukan dengan melihat hasil absorbance value yang akan ditetapkan secara uji kuantitatif dengan ELISA reader pada panjang gelombang ( $\lambda$ ) $412 \mathrm{~nm}$. Aktivitas enzim secara kuantitatif kemudian dibaca dengan ELISA reader pada panjang gelombang ( $\lambda$ ) $412 \mathrm{~nm}$. Status resistensi dilihat dari hasil pembacaan intensitas warna pada Elisa reader jika absorbance value (AV) $<0.102=$ rentan, AV $0.102-1.254=$ toleran dan $\mathrm{AV}>1.254=$ resisten 


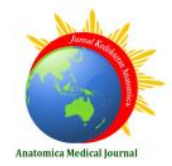

E-ISSN: 2614-5219

\section{HASIL PENELITIAN}

\section{Uji susceptibilitas/bioassay}

Uji resistensi larva Aedes aegypti terhadap insektisida karbamat dilakukan pada 276 larva nyamuk Aedes aegypti yang sudah dikumpulkan sebelumnya. Semua larva yang sudah dikumpulkan tadi dilakukan uji susceptibilitas/bioassay menggunakan temephos $0.02 \mathrm{mg} / \mathrm{L}$ (sesuai dengan standart WHO). Larva nyamuk Aedes aegypti tadi dimasukkan ke dalam gelas beaker yang berisi temephos $0.02 \mathrm{mg} / \mathrm{L}$ dan didiamkan selama 1 jam. Setelah didiamkan selama 1 jam, terlihat larva yang mati dan larva yang masih hidup. Larva yang sudah mati dikumpulkan dan dihitung berapa jumlahnya, begitu juga dengan larva yang masih hidup. Larva yang mati dianggap larva yang rentan terhadap insektisida karbamat.

Tabel 4.1. Hasil uji bioassay larva nyamuk Aedes aegypti

\begin{tabular}{llcc}
\hline No. & Hasil & Jumlah & Persentase \\
\hline 1. & Larva hidup & 93 & $33.7 \%$ \\
\hline 2. & Larva mati & 183 & $66.3 \%$ \\
\hline & Total & 276 & $100 \%$
\end{tabular}

Dari tabel 4.1 terlihat dari 276 larva nyamuk Aedes aegypti yang diuji menggunakan temephos $0.02 \mathrm{mg} / \mathrm{L}$, itu didapatkan 183 larva yang mati dan sebanyak
93 larva yang hidup. Larva Aedes aegypti yang mati itu adalah larva yang rentan terhadap insektisida karbamat. Sedangkan larva yang hidup adalah larva yang resisten insektisida karbamat. Larva yang masih hidup tadi kemudian dimasukkan ke dalam gelas ukur yang berisikan air bersih untuk selanjutnya dilakukan uji aktivitas enzim asetilkolinesterase.

\section{Uji aktivitas enzim asetilkolinesterase}

Uji aktivitas enzim asetilkolinesterase dilakukan pada larva Aedes aegypti sebanyak 93 larva yang masih hidup pada uji susceptibilitas/bioassay. Uji ini dilakukan dengan mengukur absorbance value (AV) dengan menggunakan ELISA reader pada panjang gelombang $(\lambda) 412 \mathrm{~nm}$.

Data yang telah didapatkan selanjutnya dianalisis secara deskriptif dengan menggunakan penentuan status resistensi berdasarkan kriteria berikut :

1. Rentan : jika absorbance value $(\mathrm{AV})<$ 0.102

2. Toleran : jika absorbance value (AV) $0.102-1.254$ 
3. Resisten : jika absorbance value (AV) > 1.254

Hasil pengukuran nilai absorbance value (AV) larva Aedes aegypti di Kecamatan Medan Denai yaitu :

Tabel 4.2 Hasil uji aktivitas enzim asetilkolinesterase pada larva nyamuk Aedes aegypti

\begin{tabular}{clccc}
\hline No. & Status Resistensi & Nilai AV & Jumlah & Persentase \\
\hline 1 & Rentan & $<0.102$ & 0 & $0 \%$ \\
\hline 2 & Toleran & $0.102-1.254$ & 93 & $100 \%$ \\
\hline 3 & Resisten & $>1.254$ & 0 & $0 \%$ \\
& & & & \\
\hline
\end{tabular}

Pada tabel 4.2 dapat dilihat bahwa hasil pemeriksaan yang telah dilakukan pada 93 larva nyamuk Aedes aegypti menunjukkan bahwa seluruh larva termasuk kedalam kelompok toleran terhadap insektisida karbamat dan tidak ditemukan larva yang masuk kedalam kelompok resisten terhadap insektisida karbamat.

Maka secara keseluruhan status resistensi larva yang diperiksa adalah sebagai berikut :

Tabel 4.3 Status resistensi larva nyamuk Aedes aegypti di Kecamatan Medan Denai

\begin{tabular}{clcc}
\hline No. & Status Resistensi & Jumlah & Persentase \\
\hline 1 & Rentan & 183 & $66.3 \%$ \\
\hline 2 & Toleran & 93 & $33.7 \%$ \\
\hline 3 & Resisten & 0 & $0 \%$ \\
\hline & Total & 276 & $100 \%$ \\
\hline
\end{tabular}

Pada tabel 4.3 bahwa status resistensi larva Aedes aegypti yang dikumpulkan dari beberapa rumah yang ada di Kecamatan Medan Denai yaitu larva nyamuk yang rentan terhadap insektisida karbamat sebesar $66.3 \%$, sedangkan larva yang toleran sebesar $33.7 \%$ dan larva yang resisten itu tidak dijumpai.

\section{PEMBAHASAN}

Penelitian yang dilakukan ini menggunakan larva nyamuk Aedes aegypti yang dikumpulkan dari beberapa rumah di Kecamatan Medan Denai yang itu merupakan salah satu daerah yang endemik demam berdarah dengue di kota Medan. Penelitian yang serupa dengan penelitian ini belum pernah di teliti sebelumnya. Sehingga dapat dijadikan data dasar bagi peneliti lainnya menjadi bahan pembanding dengan melihat status resistensi larva nyamuk Aedes aegypti terhadap insektisida golongan karbamat. Berdasarkan hasil penelitian yang didapat pada 276 larva, diketahui bahwa sebesar 


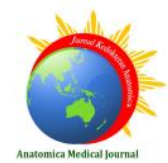

E-ISSN: 2614-5219

33.7\% larva Aedes aegypti toleran terhadap insektisida karbamat.

Dalam terjadinya resistensi terhadap insektisida pada beberapa serangga dipengaruhi oleh beberapa faktor. Faktor pertama itu adalah faktor genetik yaitu berupa gen yang menyandi pembentukan enzim eseterase, yang dapat menyebabkan resistensi serangga terhadap insektisida. Faktor kedua adalah faktor operasional meliputi bahan kimia yang digunakan dalam pengendalian vektor serta aplikasi insektisida berupa cara aplikasi, frekuensi dan lama penggunaan. Dan faktor yang ketiga adalah faktor biologis yang meliputi biotik (adanya perkawinan monogami atau poligami, pergantian generasi), perilaku serangga seperti migrasi, isolasi, serta kemampuan serangga melakukan perlindungan terhadap bahaya. ${ }^{23}$

Resistensi dapat terjadi dengan mekanisme penurunan sensitivitas pada sistem saraf dan aktivitas enzim asetilkolinesterase dalam tubuh serangga. Adanya resistensi juga dapat disebabkan oleh resistensi silang dengan sesama insektisida dengan sisi target yang sama yaitu asetilkolinesterase. Resistensi terjadi karena kemampuan serangga untuk memodifikasi kutikula atau lapisan saluran pencernaannya sehingga mencegah/memperlambat absorbsi insektisida. Selain itu adanya kemampuan serangga untuk menghindar dari efek mematikan insektisida dengan perubahan perilaku dalam merespon adanya penyemprotan insektisida. ${ }^{8}$

Berdasarkan penelitian tentang resistensi Aedes aegypti terhadap insektisida karbamat, menyebutkan bahwa penggunaan insektisida karbamat dalam jangka waktu lama akan menginduksi terjadinya resistensi terhadap bahan aktifnya. ${ }^{7,8}$

Pada penelitian yang ini ditemukan bahwa sekitar $33.7 \%$ larva sudah menunjukkan toleran sehingga ini harus diwaspadai bahwa sudah mulai terjadi resisten sedang terhadap insektisida karbamat. Dapat dilakukan cara untuk menanggulangi masalah larva nyamuk Aedes aegypti yang toleran terhadap insektisida karbamat agar tidak menjadi resisten, diperlukan pengendalian terhadap penggunaan insektisida secara terkontrol. $^{12}$

Selain itu diperlukan juga penggantian penggunaan insektisida karbamat dengan bioinsektisida yang lain seperti bakteri Bacillus thuringiensis israeliensis (Bti). Penggunaan bakteri ini dilaporkan efektif mengendalikan larva dan sebagai 


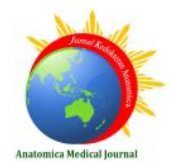

E-ISSN: 2614-5219

pengendalian penyebab penyakit demam berdarah dengue baik untuk larva maupun untuk nyamuk dewasa merupakan alternatif yang baik setelah penggunaan insektisida kimiawi dikurangi. ${ }^{6,17}$

Cara yang sudah sering dilakukan untuk pemberantasan sarang nyamuk itu adalah dengan metode 3M (menguras bak mandi, menutup lokasi perkembangbiakan nyamuk, dan mngubur barang bekas yang dapat menjadi sarang nyamuk atau genangan air). Secara konsep gerakan pemberantasan sarang nyamuk dengan $3 \mathrm{M}$ ini seminggu sekali cukup untuk memotong atau menghilangkan siklus hidup nyamuk tersebut. ${ }^{15,17}$

Cara pengendalian dengan menggunakan predator alami untuk larva Aedes aegypti juga sudah dilakukan seperti ikan cupang (Ctenops vittatus), ikan kepala timah (Panchax panchax). Untuk pengendalian fisik-mekanik secara individual dapat dilakukan dengan menggunakan reppellent, menggunakan pakaian yang berbahan lengan panjang dan celana yang panjang, dapat juga dengan memasang kelambu pada tempat tidur dan kawat anti nyamuk pada jendela. ${ }^{6}$

\section{KESIMPULAN}

Berdasarkan hasil penelitian dan pembahasan uji resistensi larva nyamuk Aedes aegypti terhadap insektisida karbamat di kecamatan Medan Denai, maka dapat disimpulkan sebagai berikut:

1. $66.3 \%$ larva Aedes aegypti rentan terhadap insektisida golongan karbamat

2. $33.7 \%$ larva Aedes aegypti toleran terhadap insektisida golongan karbamat

3. Tidak ada (0\%) larva Aedes aegypti resisten terhadap insektisida golongan karbamat

\section{SARAN}

Setelah dilakukannya penelitian tentang uji resistensi larva Aedes aegypti terhadap insektisida golongan karbamat di Kecamatan Medan Denai, maka peneliti memberikan beberapa saran antara lain :

1. Menggalakkan program pemberantasan sarang nyamuk (PSN) dengan cara 3M yaitu menguras bak, menutup dan mengubur barang yang sudah tidak dipakai

2. Mensosialisasikan tata cara penggunaan insektisida yang baik dan benar 


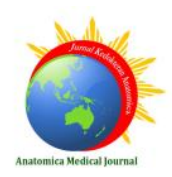

E-ISSN: 2614-5219

3. Bagi pemerintah agar melakukan pemantauan terhadap kerentanan nyamuk Aedes aegypti terhadap insektisida

\section{DAFTAR PUSTAKA}

1. Ishartadiati K. Aedes aegypti Sebagai Vektor Demam Berdarah Dengue DBD. Univ Wijaya Kusuma Surabaya. 2009:8.

2. Dewi R, Astuti I, Siswanti LH, Suhartini A. Sebaran Vektor Penyakit Demam Berdarah Dengue ( Aedes aegypti) di Universitas Islam Bandung. Journal Global Medical and Health Communication. 2015;4(2):82-86.

3. Sayono, Qoniatun S, Mifbakhuddin. Pertumbuhan Larva Aedes aegypti pada Air yang Tercemar. Jurnal Kesehatan Masyarakat Indonesia. 2011;7(1):15-22.

4. Rahayu N, Sulasmi S, Suryatinah Y. Status kerentanan Aedes aegypti terhadap beberapa golongan insektisida di Provinsi Kalimantan Selatan. Journal of Health Epidemiology and Communicable Disease. 2018;3(2):56-62.

5. Dinas Kesahatan Provinsi Sumatera Utara. Profil Kesehatan Sumatera Utara 2012. Profil Kesehatan Sumatera Utara 2012. 2012:23. http://diskes.sumutprov.go.id.
6. Kementerian Kesehatan RI. Demam Berdarah Dengue. Buletin Jendela Epidemiologi. 2010;2:48.

7. Lesmana SD. Resistensi Aedes aegypti terhadap Insektisida Golongan Organofosfat. Jurnal Ilmu Kesehatan. 2010;4(1):10-13.

8. Firmanta Y. Deteksi Resistensi Nyamuk Aedes aegypti yang Berasal Dari Daerah Endemis Dan Non Endemis Dengue di Kota Jambi Berdasarkan Aktivitas Enzim Esterase Non Spesifik Terhadap Insektisida Golongan Piretroid. 2008. Skripsi Oleh Yusuf Firmanta

9. WHO (World Health Organization). Test procedures for insecticide resistance monitoring in malaria vector mosquitoes. World Health Organisation Tech Rep Ser. 2013:22. doi:10.1007/978-3-64210565-4

10. WHO. Global Plan For Insecticide Resistance Management in Malaria Vektor. 2012.

11. Nusa R, Ipa $M$, Delia $T$, Santi $M$. Penentuan Status Resisteni Aedes aegypti dari Daerah Endemis DBD di Kota Depok terhadap Malathion. Buletin Penelitian Kesehatan. 2008;Vol. 36 No(4):20-25. 


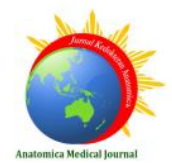

E-ISSN: 2614-5219

12. Widiastuti D, Sunaryo. Aktivitas Enzim Esterase Pada Populasi Nyamuk Aedes aegypti Terhadap Malation di Tiga Kabupaten di Provinsi Daerah Istimewa Yogyakarta. Jurnal Ekologi Kesehatan.Yogyakarta. 2018;16 (3):150157.

13. Wati, Ratianingsih R, Jaya AI. Mengkaji Model Pengendalian Populasi Aedes Aegypti Dengan Sterile Insect Tehnique (Sit) Dan Kombinasinya Dengan Insektisida. Online Jurnal of Natural Science. 2014;3(1):75-88. doi:10.13663/j.cnki.lj.2014.08.002doi:10 .13663/j.cnki.lj.2014.08.002

14. Widawati M, Nurul H Kusmastuti. Insektisida Rumah Tangga dan Keberadaan Larva Aedes aegypti di Jakarta Selatan. Jurnal Aspirator. 2017;9(November 2015):35-42.

15. Suyanto, Sri Darnoto dan DA. Pengendalian Nyamuk Aedes aegypti Di Kelurahan Sangkrah Kecamatan Pasar Kliwon Kota Surakarta. Jurnal Kesehatan. 2011;4:1-13.

16. Pambudi BC, Tarwotjo U, Hestiningsih R. Efektivitas temephos sebagai larvasida pada stadium pupa Aedes aegypti. Jurnal Kesehatan Masyarakat. 2018;6 (1):381-
388.

17. Supartha, IW. Pengendalian Terpadu Vektor Virus Demam Berdarah Dengue, Aedes aegypti ( Linn .) dan Aedes albopictus (Skuse) (Diptera: Culicidae). Makalah disampaikan dalam Seminar DiesUnud 2008. 2008;(September):1-18.

18. Karauwan, Indri, Janno B B, Bernadus GPW. Uji Resistensi Nyamuk Aedes aegypty Dewasa Terhadap Cypermethrin di Daerah Pasar Tua Bitung 2016. Jurnal Kedokteran Klinik (JKK). 2017;1(3):4246.

19. Sari M, Biologi J. Perkembangan Dan Ketahanan Hidup Larva Aedes aegypti Pada Beberapa Media Air Yang Berbeda. skripsi oleh muna sari. 2017.

20. Candra A. Demam Berdarah Dengue: Epidemiologi, Patogenesis, dan Faktor Risiko Penularan. Jurnal Aspirator. 2010;2(2):110-119.

21. WHO. Framework for a National Plan for Monitoring and Management of Insecticide Resistence in Malaria Vector.; 2017.

22. Soenjono SJ. Status Kerentanan Nyamuk Aedes sp. (diptera:culicidae) Terhadap Malation dan Aktivitas Enzim Esterase Non Spesifik di Wilayah Kerja Kantor 
E-ISSN: 2614-5219

Kesehatan Pelabuhan Bandar Udara Sam

Ratulangi Manado. Jurusan Kesehatan Lingkungan. 2007:1-6.

23. Pradani FY, Ipa M, Marina R, Yuliasih Y. Status Resistensi Aedes aegypti dengan Metode Susceptibility di Kota Cimahi terhadap Cypermethrin. Journal of Health Epidemiology and Communicable Disease. 2017; 3 (2):18-24.

24. Pratamawati DA, Irawan AS. Hubungan Antara Perilaku Penggunaan Insektisida Rumah Tangga Dengan Riwayat Pernah Sakit Demam Berdarah Dengue di Provinsi Bali Tahun 2011. Jurnal
Spirakel. 2015;7(2):15-27.

25. WHO. Indoor Residual Spraying an Operational Manual for Indoor Residual Spraying (IRS) for Malaria Transmission Control and Elimination. 2015.

26. Setyowati, E.A. Biologi Nyamuk Aedes aegypti Sebagai Vektor Demam Berdarah Dengue. Universitas Jenderal Soedirman. 2013.

27. Sungkar, S. Bionomik Aedes Aegypti, Vektor Demam Berdarah Dengue. Majalah Kedokteran Indonesia. 2005; 55 (4): $384-389$ 